\title{
Intrapartum Uterine Rupture
}

National Cancer Institute

\section{Source}

National Cancer Institute. Intrapartum Uterine Rupture. NCI Thesaurus. Code $C 114372$.

An acute symptomatic tearing of the uterine wall after the onset of labor. 